\title{
Literary Development during Sur Afghan period
}

\section{Saba Samreen Ansari}

\begin{abstract}
The Medieval India saw a great advancement in the progress of Indian language and literature. Persian and Arabic are the most important literary works of the Afghan period. Hindi literature also made a significant progress during this period. Braj bhasha and khari boli Begun were usage in literary compositions. This article attempt to examine that there are many scholars and theologians who contribute in the growth of literature. Malik Mohammad Jayasi and Surdas are the most famous figure from this period.
\end{abstract}

Keyword: Literature, Afghan, development, progress, Scholar, Theologian, Poet.

* Ph.D. Research Scholar, Department of History, Aligarh Muslim University, Aligarh, India 


\section{Introduction}

Literature is the mirror, which reflects the culture and character of people. It is equally applicable on the literature of both classes, the elites and that of the masses. The Sur Afghan rule occupies a significant position in literary history. In this period, a prominent progress in Arabic and Persian learning is observe. It witnessed a momentous development of the Hindi language and literature. ${ }^{1}$ Like the Muslim poets, Hindi poets were also attach to the Sher Shah's court. After his death his successor Islam Shah continued the policy and progresses' the name and fame of the dynasty. The poets and writer of this period are classified as under:-

\section{Arabic and Persian Scholars and Theologians}

Mir Sayyid Rafiuddin, Mullah Jalal Bhim Danishmand, Shaikh Mubarak and Shaikh Budh Tabib Danishmand were some of the celebrated men of the Sur period.

Mir Sayyid Rafiuddin: Syed Rafiuddin Shirazi was among the ninth century $(\mathrm{AH})$ authorities on Hadith and a great man of learning. According to Akhbar al-Akhyar, Rafiuddin's family was greatly respected in Shiraz, so much so that Allama Dawwani himself would come to his house to teach him. Rafiuddin himself went to Cairo and stayed there for a long time as his disciple. In his book, Zau-ul-Laame fi A'yan-ul-Qarn-al-Tasey, Sakhawi has written a detailed treatise about him. He came to India during the reign of Sultan Sikandar Lodhi and settled there. All kings from Sikandar Lodhi to Salim Shah were his murids (disciples). Great ulama also were his disciples in the Science of Hadith. Mir Sayyid Rafiuddin the renowned and unique traditionalist whom Sher Shah used to consult on vital matters, religious as well as temporal. ${ }^{2}$ Defeated by Sher Shah, Mughal king Humayun came to Agra and met Rafiuddin at his residence seeking his blessings and supplications. Tazkirat al-Waqiaat says that Rafiuddin had suggested to Humayun to go to Iran.

Shaikh Mubarak: Shaikh Mubarak is the illustrious father of the great historian Abul Fazal and Shaikh Faizi. He occupied a prominent position among the scholars. His views were angrily debated by the orthodox, who blamed him of opportunism and flattery. He was the authors of many books

Abdur Rahim, History of the Afghans in India A.D. 1545- 1631, Karachi, 1961, p. 145

Abdul Qadir Badauni, Muntakhab- al- Tawarikh, vol. I (tr.) Ranking, Calcutta, Asiatic Society, 1925, pp. 479- 81 
in Arabic and Persian. A commentary on the Quran, Manba-i- nafais- ul- uyum and translation into Persian of the classical work zoological science written

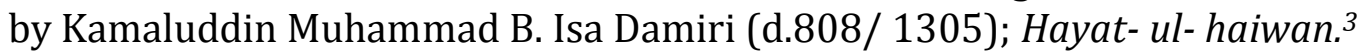

Shaikh Budh Tabib Danishmand: He was a distinguish theologian of this time. According to Badauni ,Shaikh Budh Danishmand was distinguish for learning and piety and Sher Shah had so much respect for him that he often helped the Shaikh in putting on his shoes.

Maulana Abdullah Sultanpuri: The outstanding figure of the Sur period in Arabic, Persian and Islamic learning was Maulana Abdullah Sultanpuri. He was also a great theologian of that time. Humayun distinguishes him with the title of Makhdum- ul- mulk and allows him considerable power in religious matters. Sher Shah made him the Shaikh- ul- Islam and Islam Shah gave him the post of Sadr- us- sudur. ${ }^{4}$ In matters relating to religion and grants to religious learned persons and educational institutions, the king usually took advice from him. Islam shah had great respect for the learning of his Sadr- ussudur. His beneficence of the learned was unlimited. Badauni highly appreciated his literary and intellectual attainments. He says that Maulana was one of the vastly learned men of the age and was in -comparable especially in the knowledge of the Quran and hadith, theology and law. He wrote two important books Ismat- $i$ - ambiya and a commentary on the Shamali- un- nabi, which were considered the best of his compositions. He had great influence in the state and society. ${ }^{5}$

Shaikh Hasan and Shaikh Nasr Allah: Hasan, father of Shaikh Alai and his uncle Shaikh Nasr Allah also were learned men of the Sur period. Originally, they belong to the Bengal, later settled in Biana and devoted themselves to teaching and preaching. ${ }^{6}$

Jahangir Hashmi: During the reign of Sher Shah Suri, the Afghan monarch, Jahangir for few years stayed in Delhi, the imperial capital and treated with respect for his pious background. He composed a masnavi on the pattern of

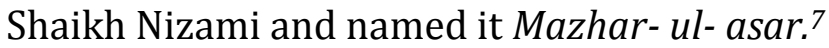

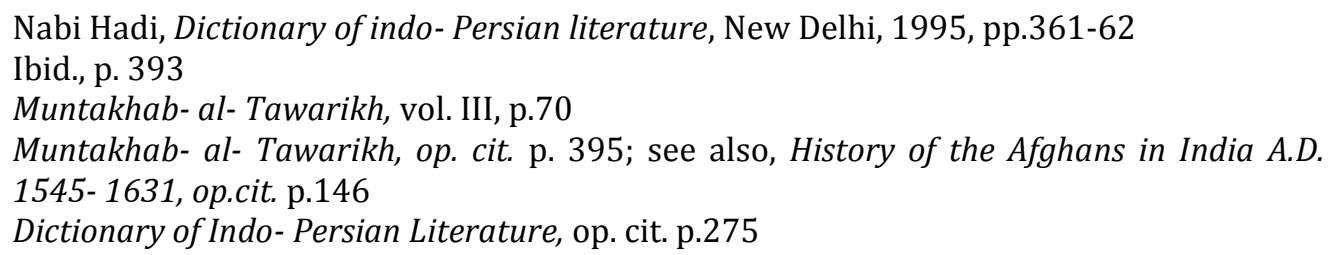


Shaikh Alai: He was also a great Islamic learner of that time. He excelled in Islamic learning and he rise above in religious debate with all the other celebrated scholars of that period.

\section{Persian poets}

Persian poetry occupied next place in this period. Badauni gives the name of some talented poets who flourished in the Sur court. Mir Sayyid Naimatullah, Shaikh Abdul Hai, Haiti, Saifi earned fame in verification and learning. ${ }^{8}$

Mir Sayyid Naimatullah: Badauni says that Mir Sayyid Naimatullah, known by his poetical name as Rushuti, who was an incomparable learned man of the age, was his constant companion. ${ }^{9}$

Shaikh Abdul Hai: He was the son of Shaikh Jamali Kanbawi of Delhi. He was a vastly learned man and a poet, and was a devout man. Sayyid Shah Mir of Agra invented the following chronogram:-

My name in itself would furnish the Tarikh

At such time as 'abd (the slave) was not in the midst of it.10

\section{Hindi poets}

The Hindi language and literature made unprecedented progress in the Sur afghan period. The afghan rulers extended liberal patronage to the Hindi poets and scholars. They were keenly interested in the promotion of Hindi and they advanced it in every conceivable way. They were the first to accord it a status of dignity in the state and society. The court of Islam Shah Sur in particular was by all indications a congenial place for Hindi writer. The Sufi concerned were Malik Muhammad Jayasi author of Padmavat, Mir Sayyid Manjhan composer of Madhumalati and Shaikh Qutban writer of Mirgavati. They were the three sixteenth century Sufi poets of Hindi. Shaikh Kabir Batni in his Afsana- i- shahan mentions the name of Surdas along with Muhsin who were also attached to the royal court. ${ }^{11}$ Some other great Hindi poets, such as Shah Muhammad Farmuli, Haridas and Tulsidas also flourished in the Sur period.

\footnotetext{
Muntakhab-al- Tawarikh, op. cit. p. 410

Ibid., p.415

Ibid., p.410

Muhammad kabir, Afsana- i- Shahan, f. 105b
} 


\section{Sufi Poets}

Malik Muhammad Jayasi: Malik Muhammad Jayasi was the oldest vernacular poet, composed his famous work Padmavat in $1540 \mathrm{CE}$, when Sher Shah was the Sultan of Delhi. The other work composed by him was Akhravata. Both of his works are written in Awadhi language. Padmavat is the only romantic epic of Hindi literature in masnavi form of poetry. The epic poem is a fictionalized version of the historic siege of Chittor by Alauddin Khilji in 1303 CE, who attacks Chittor after hearing of the beauty of Queen Rani Padmini, the wife of King Rawal Ratan Singh. ${ }^{12}$ It is a 'tale of love'. It is an allegory depicting transcendental love through the medium of unearthly love- story. ${ }^{13}$

According to Jayasi, Chittor stood for body, Raja for mind, Ceylon for heart, Padmini for wisdom, Alauddin for lust. For this, Ashraf Jahangir Semnani as an ideal spiritual guides.

Though fanciful, the Padmavat is however a master- piece of the Hindi literature. It reveals Jayasi as a mystic. Some part of the work is dedicate to Sher Shah (1486-1545 CE). Jayasi compares Sher Shah with Umar the second Caliph of Islam for his love and justice. ${ }^{14}$

Mir Manjhan: Mir Manjhan wrote his famous Madhumalati during the reign of Islam Shah, in 1545 CE. The Madhumalati is a mystical Indian romance. Similarly, Mir Manjhan praises Islam Shah in his prologue as the king of the time that every person benefited from his impartial justice and peace and prosperity prevailed everywhere in his empire due to his just rule. ${ }^{15}$

Qutban Shaikh: He completed his work in 1558 CE and dedicated his work to Alauddin Hussain Shah of Bengal, whom he calls the one well versed in the

Padmavat ; the Imperial Gazetteer of India, vol. 2, 1909, p. 430

Amaresh Dutta, Encyclopedia of Indian Literature, vol. II, New Delhi, 1988, p.1178

Iqtidar Hussain Siddiqui, Some Aspects of Afghan Despotism in India, Aligarh, 1969, p.87

Mir Manjhan, Madhumalati, ed. Mata Prasad Gupta, Allahabad, 1861, p. 12 
Purana and whose courage and justice he compares to Hindu heroes of the Mahabharata fame. ${ }^{16}$

\section{Bhakti Poets}

The Bhakti Movement of that time also made a significant contribution to the development of Hindi language and literature. The eight disciples of Goswami Vallabhacharya, known as hast- chap, were also notable poets of the Braj Bhasa Hindi.

Surdas: Surdas was the sun in the sky of Hindi literature. Surdas flourished under the court patronage of Islam Shah. ${ }^{17}$ Surdas knew the Persian and used Persian words and idioms in Hindised forms. He has earned undying fame for his poetical work Sursagar, Sursravali, Sahityalahri. His chief fame as a poet rests on his Sursagar being a verified rendering of the Bhgvat Purana originally containing 125,000 verses. The theme of Sursagar is the boyhood of Krishna in Virindaban as described with such vividness and naturalness as to give the reader an impression that almost likes an eyewitness. ${ }^{18}$

Swami Haridas: He made a remarkable contribution in this field. Swami Haridas was a spiritual poet. He was born sometime during the latter half of the fifteenth century. Swami Haridas compositions include Hridas Ji Ki Pad, Haridas Ji Ki Granth, Swami Haridas Ji Ki Bani many of his songs have been quoted by Pandit Krishnanand Vyasdeva in his Sangi- ta- raga- kalpadruma. ${ }^{19}$ His work influenced both the classical music and the Bhakti movements of North India, especially those devoted to Krishna's consort Radha. He describes Radha and Krishna is sporting beautifully:

Two beams of light are playing,

Unique their dance and music.

16 Dr. A. Halim, Three sixteen century Sufi poets of Hindi, Proceeding Of Pakistan History Conference, Peshawar, 1958, p. 227

17 Afsana- i- Shahan, op. cit. f. 154a

18 Dr. A. Halim, A peep into the patronage of Hindi literature at Akbar's court, proceeding of Pakistan history conference, Khairpur, 1955, p. 186

19 Ibid., p. 185 
Ragas and raginis of heavenly beauty are born.

The two have sunk themselves in the ocean of raga.

Tulsidas: The celebrated Hindi poet Tulsidas the author of Ramcharitrmanas, began his poetical career in the fostering atmosphere of the Sur afghan rule. Surdas, a devotee of Krishna and a contemporary of Tulsidas, called Tulsidas as Sant Shiromani (the highest jewel among holy men) in an eight-line verse extolling Ramcharitrmanas and Tulsidas. ${ }^{20}$ Specifically about his poetry, Tulsidas is been called the "emperor of the metaphor" and one who excels in similes by several critics. The Hindi poet Ayodhya Singh Upadhyay 'Hariaudh' said of Tulsidas:-

"Tulsidas did not shine by composing poetry, rather it was Poetry herself that shone by getting the art of Tulsidas." 21

The Hindi poetess Mahadevi Verma said commenting on Tulsidas that in the turbulent middle Ages, India got light from Tulsidas. She further went on to say that, "the Indian society as it exists today is an edifice built by Tulsidas, and the Rama as we know today is the Rama of Tulsidas." 22

Narhari: A Braj poet Narhari, who had been one of several vernacular poets to attract the patronage of Islam Shah Sur (1545-1554 CE). ${ }^{23}$

Vittalnath:He was a prose- writer who wrote Sringar Rasa Mandana. He was the son of Vallabhacharya.

Shah Muhammad Farmuli: A noble of Islam Shah who composed excellent verses in Hindi. ${ }^{24} \mathrm{He}$ was a vernacular poet. Persian literary biographer

20 Usha Devi Shukla, Gosvami Tulsidas and Ramcharitamanasa, New Delhi, 2002, p. 34

21 Ram Ganesh Pandey, (The Birthplace of Tulasidasa: Investigative Research), Uttar Pradesh, 2008, p.10; Uday Bhanu Singh, (Investigation into the poetry of Tulsidas), New Delhi, 2008, p. 339

22 Gosvami Tulsidas and Ramcharitamanasa p. 11

23 Allison Busch, Poetry of kings: a classical Hindi literature of Mughal India, New York, 2011, p.134

24 Afsana- i- Shahan, f. 146a 
fondly remembers his vernacular poems. For his wit and humour he was the favourite companion of Islam Shah. ${ }^{25}$

Ahmad Al Umri: He composed a songstress on the love of Baz Bahadur and his beloved Rupmati under the title 'lady of the lotus'. He also composed many other songs, the most remarkable of which were those written in commemoration of the delights of the spring festival and of the infatuation of the gopis of Vrindaban for the melodious reed- pipe (bansi) of Krishna. ${ }^{26}$

Islam shah was also a friend of learned. He was happy among the scholars and pious people. In his patronage to learning Islam Shah surpassed his father. An indeed his encouragement gave a great stimulus to literary activities and development of the Persian language and poetry in particular. Islam shah was a good poet, and took interest in poetry, competed with great poets of the time in composing elegant verses and was highly esteemed by the learned.

Naimatullah while enumerating the traits of Islam Shah says, "He was wise, accomplished, learned, possessed of sound judgment, far- sighted, God fearing and the protector of his subjects. He memorized the Gulistan and Bustan of Sadi and very often recited the poetry of Hafez. In his gatherings, strange stories, fables and verses of the bye- gone poets were recite. He took delight in composing verses; if any verse cited, he could easily complement extempore with another verse. He had acquired acknowledge of the fundamental points of canon law from Makhdum- ul- Mulk, attended and took part in theological discussions." 27

\section{Conclusion}

The period of Sur Afghan rule saw an excellent development of the literature in Arabic and Persian but it is particularly rich in the works of the Hindi

Muntakhab-al- Tawarikh, Op.cit. p. 387

History of the Afghans in India A.D. 1545-1631, op. cit. p. 148

Muntakhab-al- Tawarikh, Op.cit. p. 416 
language and literature. The poet like Jayasi, Sur, Tulsi was a product of this period. Islam shah's patronage to the learned and his interest in philosophical discussions with them can be witness latter in history with the dawn of the intellectual renaissance that took place in the reign of Akbar. 
Jhss, Vol. 8, No. 2 , July to December, 2017

\section{References}

Abdur Rahim, History of the Afghans in India A.D. 1545- 1631, Karachi, 1961

Abdul Qadir Badauni, Muntakhab- al- Tawarikh, vol. I (tr.) Ranking, Calcutta, Asiatic Society, 1925

Nabi Hadi, Dictionary of indo- Persian literature, New Delhi, 1995

Muhammad kabir, Afsana- i-Shahan

Padmavat, The Imperial Gazetteer of India, vol. 2, 1909

Amaresh Dutta, Encyclopedia of Indian Literature, vol. II, New Delhi, 1988

Iqtidar Hussain Siddiqui, Some Aspects of Afghan Despotism in India, Aligarh, 1969

Mir Manjhan, Madhumalati, ed. Mata Prasad Gupta, Allahabad, 1861

Dr. A. Halim, The Sixteen Century Sufi poets of Hindi, Proceeding Of Pakistan History Conference, Peshawar, 1958

Dr. A. Halim, A peep into the patronage of Hindi literature at Akbar's court, proceeding of Pakistan history conference, Khairpur, 1955

Usha Devi Shukla, Gosvami Tulsidas and Ramcharitamanasa, New Delhi, 2002

Uday Bhanu Singh, Tulsi Kavya Mimansa,

Ram Ganesh Pandey, (The Birthplace of Tulasidasa: Investigative Research), Uttar Pradesh, 2008

Uday Bhanu Singh, (Investigation into the poetry of Tulsidas), New Delhi, 2008

Allison Busch, Poetry of kings: a classical Hindi literature of Mughal India, New York, 2011 